\title{
Evaluation of Diverse Soybean Germplasm for Resistance to Phomopsis Seed Decay
}

Shuxian Li, United States Department of Agriculture-Agricultural Research Service (USDA-ARS), Crop Genetics Research Unit, Stoneville, MS 38776; John Rupe and Pengyin Chen, University of Arkansas, Fayetteville 72701; Grover Shannon and Allen Wrather, Division of Plant Sciences, University of Missouri, Portageville 63873; and Debbie Boykin, USDA-ARS, Stoneville, MS 38776

\begin{abstract}
Li, S., Rupe, J., Chen, P., Shannon, G., Wrather, A., and Boykin, D. 2015. Evaluation of diverse soybean germplasm for resistance to Phomopsis seed decay. Plant Dis. 99:1517-1525.

Phomopsis seed decay (PSD), caused primarily by the fungal pathogen Phomopsis longicolla, is one of the most important diseases reducing seed quality and yield of soybean. Few cultivars have been identified as resistant. To identify new sources of resistance to PSD, 135 soybean germplasm accessions, originating from 28 countries, were field screened in Arkansas, Mississippi, and Missouri in 2009. Based on seed assays of natural field infection by $P$. longicolla in 2009, 42 lines, including the most resistant and susceptible lines, were reevaluated in the field in 2010, 2011, and 2012 with P. longicolla-inoculated and noninoculated

treatments. Six maturity group (MG) III (PI 189891, PI 398697, PI 417361, PI 504481, PI 504488, and PI 88490), four MG IV (PI 158765, PI 235335, PI 346308, and PI 416779), and five MG V (PI 381659, PI 381668, PI 407749, PI 417567, and PI 476920) lines had significantly lower percent seed infection by $P$. longicolla than the susceptible checks and other lines in the same test $(P \leq 0.05)$. They appeared to have some levels of resistance to PSD. These new sources of PSD resistance can be used in developing soybean breeding lines or cultivars with resistance to PSD, and for genetic mapping of PSD resistance genes.
\end{abstract}

Phomopsis seed decay (PSD) of soybean, Glycine max (L.) Merrill, is an economically important soybean disease that reduces seed quality and yield in most soybean-growing countries, and is prevalent in the midsouth region of the United States $(17,33)$. This seed disease is caused primarily by Phomopsis longicolla Hobbs (11), a seedborne fungal pathogen in soybean. Although other fungal pathogens in the Diaporthe-Phomopsis complex may be associated with PSD, their seed infection rate was much lower than that of $P$. longicolla (34). These pathogens primarily cause soybean stem and pod diseases, such as stem canker, which is caused by Diaporthe phaseolorum (Cooke \& Ellis) Sacc. (anamorph P. phaseoli (Desm.) Sacc.), including D. phaseolorum var. caulivora Athow \& Caldwell, and $D$. phaseolorum var. meridionalis $\mathrm{F}$. A. Fermández; and pod and stem blight, that is caused by $D$. phaseolorum var. sojae (Lehman) Wehm. (34). PSD of soybean has resulted in significant economic losses (2). Suppression of soybean yield by PSD in the top 10 soybean-producing countries was approximately 0.19 million metric tons (MMT) in 1994 (34). Estimated yield suppression due to PSD in the United States was 0.38 to 0.43 MMT from 1996 to 2007 (38). Due to the hot and humid environments in the southern United States, in 2009, soybean losses caused by PSD in 16 southern states were over 0.33 MMT (16). As reported in two studies, $P$. longicolla was routinely isolated from diseased soybean plants over a 3-year period in Canada (41) and Mississippi (27). P. longicolla can infect any soybean tissues at any growth stage of soybean but the seed are most susceptible to PSD after reaching the R7 growth stage (beginning maturity, one normal pod on the main stem has reached its mature pod color) or physiological maturity $(15,43)$.

Corresponding author: S. Li; E-mail: shuxian.li@ars.usda.gov

Mention of trade names or commercial products in this publication is solely for the purpose of providing specific information and does not imply recommendation or endorsement by the U.S. Department of Agriculture. USDA is an equal opportunity provider and employer.

Accepted for publication 12 March 2015.

http://dx.doi.org/10.1094/PDIS-04-14-0429-RE

(C) 2015 The American Phytopathological Society
Soybean seed infected by $P$. longicolla exhibit cracked seed coats that are chalky white in appearance, or shriveled and elongated seed with discoloration; or, in some cases, no external symptoms are observed $(8,28,33)$. PSD also severely affects seed germination, and reduces seedling vigor and stand establishment $(7,23,33)$. Poor seed quality caused by PSD is mostly due to the reduction of seed viability and oil content, alteration of seed composition, and increased frequency of moldy or split beans (10). PSD and the growth of $P$. longicolla are promoted under hot and humid environmental conditions, especially during pod fill through harvest $(3,31)$. This makes PSD an especially important disease in the South, where early planting (April) of early maturing cultivars has been promoted to increase yields and reduce or eliminate the need for irrigation (9). This practice, called the early soybean production system (ESPS), results in soybean maturing in August, which can also lead to low seed germination and high levels of PSD $(9,26)$.

Management of PSD includes the use of several cultural practices. For example, crop rotation to nonhost crops and conventional tillage will reduce inoculum and spore dissemination by $P$. longicolla. However, these practices do not consistently reduce disease. Promptly harvesting seed at maturity could reduce PSD but harvesting can be delayed due to wet weather (23). The use of fungicides has been reported as an option to reduce PSD and pod and stem blight; however, they are not always effective $(14,37,39,41)$. Cross et al. (5) reported that there was no significant impact on the percentage of harvested seed infected by Phomopsis spp. after applying azoxystrobin at either R3 or R6 growth stages in soybean. Planting PSD-resistant soybean cultivars would be the most economical and environmentally friendly means of managing PSD $(12,19,29,30)$ but very few resistant cultivars are currently available.

The United States Department of Agriculture (USDA) Soybean Germplasm Collection (http://www.ars-grin.gov/npgs/) housed at the University of Illinois has over 17,200 plant introductions (PI) from 92 countries. Because germplasm is a collection of natural genetic diversity, we hypothesized that soybean accessions with resistance to PSD stored in the USDA Soybean Germplasm Collection could be identified. Evaluation of soybean germplasm for resistance to PSD is the first phase of breeding high-yielding cultivars with resistance to PSD. The objectives of this study were to evaluate the reaction of a diverse subset of soybean accessions with different 
geographic origins and maturity groups (MG) III, IV, and V, and to identify new sources of resistance to PSD through multiyear field screening trials in the southern United States.

\section{Materials and Methods}

Soybean entries. In total, 135 soybean germplasm accessions, including $123 \mathrm{PI}$ and 6 resistant and 6 susceptible or general cultivar checks, were used in this study. Those PI originated from 28 countries representing diverse sets of the origins or commercial production areas in the USDA Soybean Germplasm Collection. It consisted of MG III, IV, and V (Table 1). The resistant checks (AG 4403, SN93-6012, PI 80837, UA 4805, S97-1688, and TARA) and susceptible checks (IA 3001, VINTON 81, AP 350, Vol-1702,

Table 1. Country of origin of soybean entries screened for resistance to Phomopsis longicolla

\begin{tabular}{lc}
\hline Country & Number of entries \\
\hline Algeria & 2 \\
Angola & 1 \\
Argentina & 1 \\
Belgium & 1 \\
Bulgaria & 1 \\
Canada & 2 \\
China & 16 \\
France & 6 \\
Georgia & 5 \\
Germany & 1 \\
India & 8 \\
Japan & 13 \\
Korea (North and South) & 9 \\
Morocco & 3 \\
Nepal & 3 \\
Pakistan & 1 \\
Peru & 1 \\
Poland & 2 \\
Romania & 1 \\
Russian Federation & 5 \\
South Africa & 27 \\
Taiwan & 5 \\
Thailand & 6 \\
Turkey & 2 \\
Uganda & 5 \\
United States & 13 \\
Uruguay & \\
Vietnam & 5 \\
Total & 2 \\
\hline
\end{tabular}

PI 548298, PI 371611, and PI 417420) were selected based on preliminary tests in Arkansas (P. Chen, unpublished). Soybean SUWEON97 and 5002T were used as general cultivar checks. SUWEON97 is a cultivar originally from South Korea, while $5002 \mathrm{~T}$ is a conventional cultivar for the south and a yield check for the USDA Uniform Soybean Test (http://www.ars.usda.gov/ SP2UserFiles/Place/60661000/UniformSoybeanTests/2013SoyBook. pdf). All soybean seed were obtained from the USDA Soybean Germplasm Collection in Urbana, IL and were increased in Costa Rica in 2008.

Field experiments. Field experiments were conducted at Kibler, AR on a Roxana silt loam (coarse-silty, mixed, superactive, nonacidic, thermic Typic Udifluvents) Portageville, MO on a Dundee Silt Loam (fine-silty, mixed, thermic Typic Hapludalfs); and Stoneville, MS on a Sharkey clay soil (very-fine, smectitic, thermictic Chromic Epiaquert) in 2009 to 2012. For all experiments, seed were planted at a rate of 33 seeds $/ \mathrm{m}$ of row in single-row plots $(2.74 \mathrm{~m}$ long), with a $0.91-\mathrm{m}$ row spacing in a randomized complete block design with four replications. Planting dates in each location are listed in Table 2.

Based on results of seed-plating assays of seed that were harvested from noninoculated (naturally infested) field trials in 2009, 42 accessions (14 each of MG III, IV, and V), including the most resistant and susceptible entries with the highest or lowest percentage of seed infection by $P$. longicolla in three locations, were selected and reevaluated in three states (Arkansas, Mississippi, and Missouri) in 2010 and 2011, and two states (Arkansas and Mississippi) in 2012, with $P$. longicolla spore suspension-inoculated and noninoculated treatments. In each location, experiments by MG were set up in a split-plot design. The inoculation treatment was the main plot, while MG were the subplots, and soybean entries in each MG were randomized, with four replications for each inoculation treatment. In Arkansas, irrigation water was applied via a lateralmove overhead sprinkler irrigation system every 7 to 10 days during the growing season. Approximately $2 \mathrm{~cm}$ of water was applied with each irrigation event. To promote infection, plots received irrigation following inoculation each year of the study. In Mississippi, plants were manually watered two to three times a day if needed in 2010 and 2011, and a homemade overhead sprinkle watering system was set up to promote seed infection in 2012. Approximately $250 \mathrm{ml}$ of water was used for each plot per watering time. In Missouri, the fields were furrow irrigated as needed to prevent drought conditions, with approximately $5 \mathrm{~cm}$ of water per irrigation. In the inoculated experiments, inoculations were performed at the R5 growth stage (6) each year (Table 2). Seed were manually harvested from each plot when the plants were at the R8 stage (6), weather permitting. Due to rainy conditions in 2009 and 2012, harvest was delayed 10 to 20 days for most of the entries in each location.

Table 2. Planting, inoculation, and harvest dates for screening soybean lines for resistance to Phomopsis longicolla in Arkansas (AR), Mississippi (MS), and Missouri (MO) from 2009 to 2012

\begin{tabular}{|c|c|c|c|c|c|c|c|c|}
\hline \multirow[b]{2}{*}{ State } & \multicolumn{2}{|c|}{ Planting date } & \multicolumn{3}{|c|}{ Inoculation date ${ }^{\mathrm{z}}$} & \multicolumn{3}{|c|}{ Harvest date } \\
\hline & Year & Date & MG III & MG IV & MG V & MG III & MG IV & MG V \\
\hline \multirow[t]{4}{*}{$\overline{\mathrm{AR}}$} & 2009 & 5 June & Non & Non & Non & $29 \mathrm{Sep}$ & 20 Oct & $3 \mathrm{Nov}$ \\
\hline & 2010 & 27 May & 17 Aug & 17 Aug & $7 \mathrm{Sep}, 14 \mathrm{Sep}$ & 21-28 Sep & $21 \mathrm{Sep}-12 \mathrm{Oct}$ & $5-21 \mathrm{Oct}$ \\
\hline & 2011 & 8 June & $1 \mathrm{Sep}$ & $1 \mathrm{Sep}, 7 \mathrm{Sep}$ & $13 \mathrm{Sep}$ & 21-29 Sep & $29 \mathrm{Sep}-13 \mathrm{Oct}$ & 6-14 Oct \\
\hline & 2012 & 24 May & 30 Aug & 6 Sep & $6 \mathrm{Sep}$ & 11-20 Sep & 20 Sep -2 Oct & $22 \mathrm{Oct}$ \\
\hline \multirow[t]{4}{*}{ MS } & 2009 & 20 May & Non & Non & Non & 28 Aug $-10 \mathrm{Sep}$ & 8-25 Sep & $30 \mathrm{Sep}-19 \mathrm{Oct}$ \\
\hline & 2010 & 25 May & 29 July, 17 Aug & 29 July, 17 Aug & 17 Aug, 25 Aug & 27 Aug -7 Sep & $1-14$ Sep & 14-27 Sep \\
\hline & 2011 & 20 May & 28 July, 10 Aug & 10 Aug, 15 Aug & 15 Aug, 25 Aug & $1-13$ Sep & 13-30 Sep & 4-5 Oct \\
\hline & 2012 & 25 April & 19 July, 31 July & 19 July, 31 July & 31 July, 13 Aug & 14 Aug -5 Sep & 21 Aug -14 Sep & $21 \mathrm{Sep}-12 \mathrm{Oct}$ \\
\hline \multirow[t]{3}{*}{ MO } & 2009 & 21 May & Non & Non & Non & $22 \mathrm{Sep}-1 \mathrm{Oct}$ & $20 \mathrm{Sep}-3 \mathrm{Oct}$ & 10-19 Oct \\
\hline & 2010 & 24 May & Non & Non & Non & 15-24 Sep & $26 \mathrm{Sep}-7 \mathrm{Oct}$ & $11-22$ Oct \\
\hline & 2011 & 18 May & 27 July, 10 Aug & 31 July, 15 Aug & 15 Aug, 2 Sep & 5-16 Sep & $23 \mathrm{Sep}-2 \mathrm{Oct}$ & $8-21$ Oct \\
\hline
\end{tabular}

\footnotetext{
z Soybean plants were inoculated with spore suspension of Phomopsis longicolla $\left(1\right.$ to $\left.1.5 \times 10^{5} / \mathrm{ml}\right)$ at the R5 growth stage. $\mathrm{MG}=\mathrm{maturity}$ group, Aug $=$ August,
} Sep $=$ September , and Oct $=$ October. Non $=$ noninoculated trial; plants were sprayed or irrigated with water. 
Inoculum preparation and application. Isolates of $P$. longicolla (AR-1, MSPL10-6, and MO-1), isolated from field-grown seed, were used for inoculation in the trials in Arkansas, Mississippi, and Missouri, respectively. The identification of these isolates as $P$. longicolla was confirmed by morphological analyses (11) and analysis of the internal transcribed spacer (ITS) region of ribosomal DNA amplified by polymerase chain reaction (PCR) with primers ITS1 (5'-TCCGTAGGTGAACCTGCGG-3') and ITS4 (5'-TCC TCCGCTTATTGATATGC- $\left.3^{\prime}\right)$. The isolates were grown at $24^{\circ} \mathrm{C}$ on potato dextrose agar (Difco Laboratories) adjusted to $\mathrm{pH} 4.8$ with $25 \%$ lactic acid after autoclaving. To prepare the inoculum, cultures were induced to sporulate under a fluorescent light output of $300 \mu \mathrm{mol} \mathrm{m} \mathrm{m}^{-2} \mathrm{~s}^{-1}$ with a 12 -h photoperiod for 30 to 45 days. Sporulating cultures were flooded with sterile deionized water three times, agitated to dislodge conidiospores, and filtered with four layers of sterile cheesecloth to eliminate the agar. Conidiospore concentrations were adjusted to approximately $1.5 \times 10^{5} \mathrm{ml}^{-1}$ with a hemacytometer (Hausser Scientific). In Mississippi and Missouri, a battery-operated backpack sprayer (30 psi) with a hand-held boom containing a single nozzle with an adjustable orifice was used to inoculate plants with the conidiospore suspension. The spray was directed mostly at the pods on the stem and then evenly across the foliage. In Arkansas, inoculum was adjusted to 1 to $1.5 \times 10^{5}$ conidiospores $\mathrm{ml}^{-1}$ and applied with a $\mathrm{CO}_{2}$ backpack sprayer using a TeeJet AI110015VS flat fan nozzle (TeeJet Technologies) that delivered 0.13 gallons per minute (gpm) at 30 psi. Plots were sprayed to runoff. Approximately $250 \mathrm{ml}$ of conidiospore suspension was used to inoculate each plot in each location.

Seed assays. Seed assays were conducted to determine the percent seed infected by $P$. longicolla, percent standard seed germinations, and visual seed quality of the 135 lines in 2009 and 42 lines in 2010, 2011, and 2012. For seed plating, 30 to 50 arbitrarily chosen seeds from each plot in each trial after harvest were assayed. Seed were surface disinfected in $0.5 \%$ sodium hypochlorite for $3 \mathrm{~min}$, rinsed in sterile distilled water, and then placed on potato dextrose agar (Difco Laboratories) adjusted to $\mathrm{pH} 4.8$ with $25 \%$ lactic acid after autoclaving, as previously reported $(20,22,24)$. In all, 5 (in Missouri and Mississippi) or 10 (in Arkansas) seeds were placed on each petri dish. $P$. longicolla was identified using morphological characteristics according to Hobbs et al. (11) after 4 days of incubation at $24^{\circ} \mathrm{C}$. The number of seed infected with $P$. longicolla was recorded and calculated as percent seed infection. A 100-seed sample

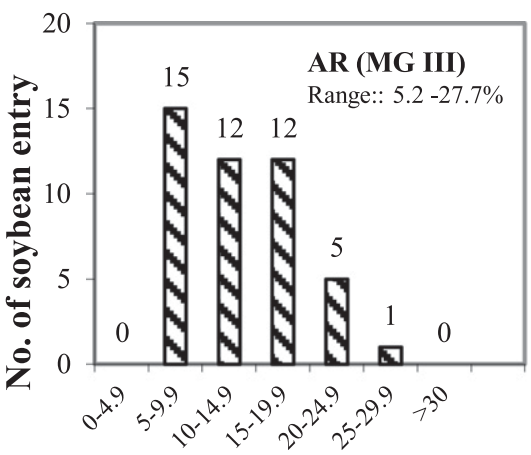

Phomopsis seed infection (\%)

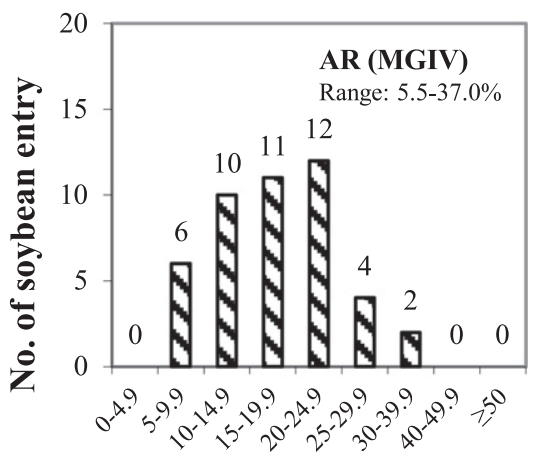

Phomopsis seed infection (\%)

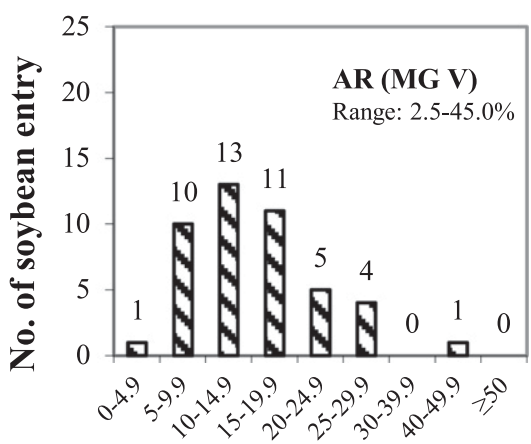

Phomopsis seed infection (\%)

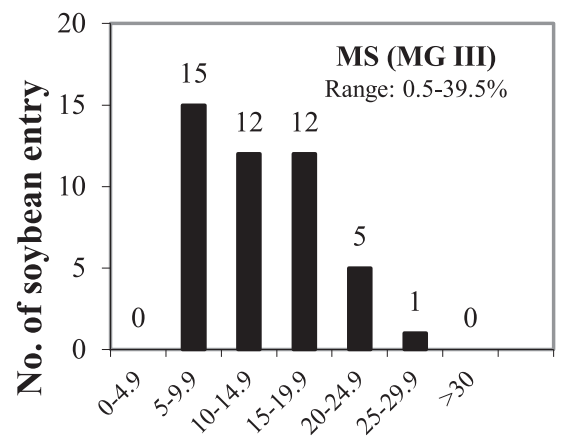

Phomopsis seed infection (\%)

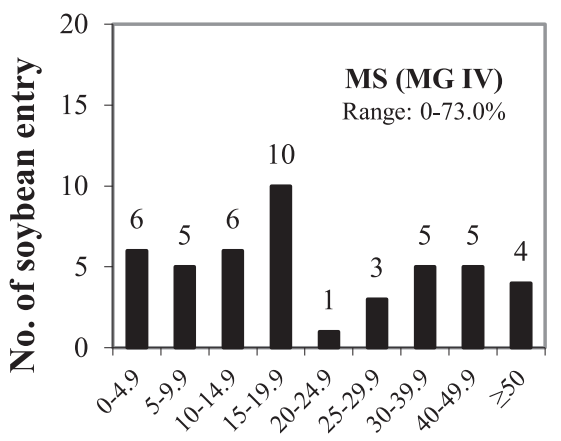

Phomopsis seed infection (\%)

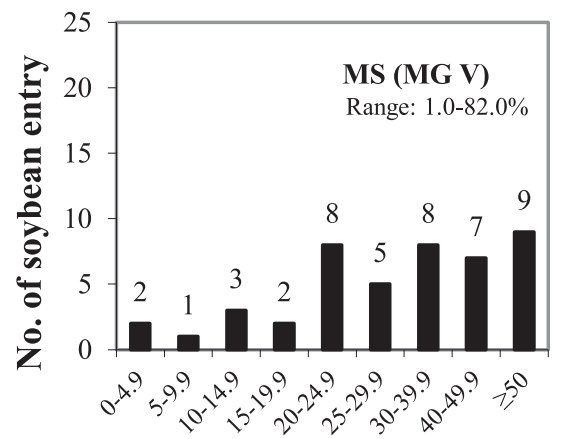

Phomopsis seed infection (\%)

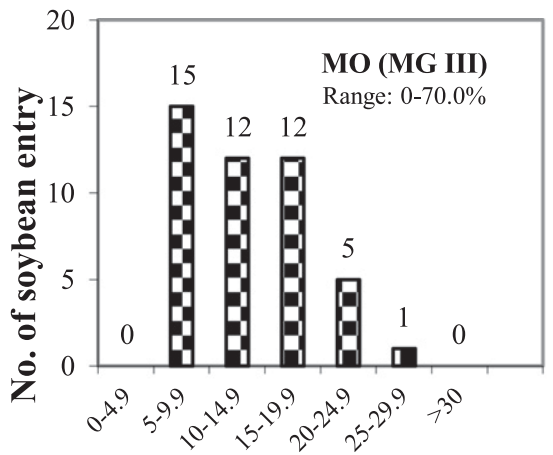

Phomopsis seed infection (\%)

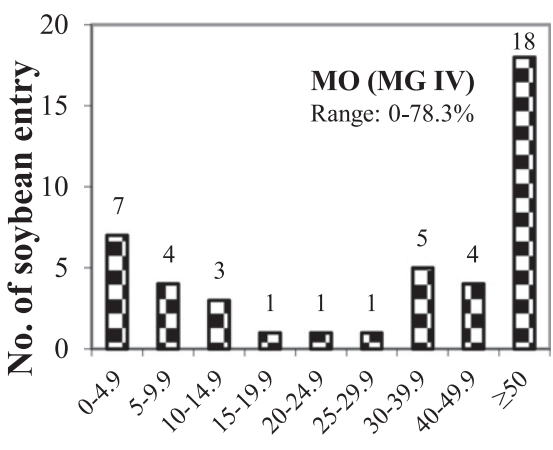

Phomopsis seed infection (\%)

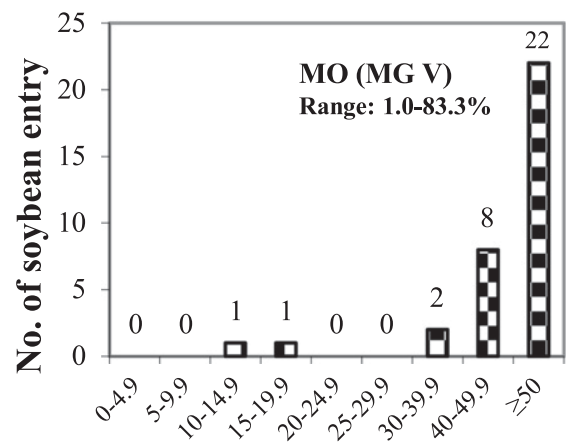

Phomopsis seed infection (\%)

Fig. 1. Frequency distribution of soybean entries with seed naturally-infected by Phomopsis longicolla that was determined by seed plating on acidified potato dextrose agar in 2009 . $M G=$ maturity group, $A R=$ Arkansas, $M S=$ Mississippi, and MO = Missouri. 
from each plot was arbitrarily taken to test for standard seed germination (1). For visual scoring of seed quality, a scale of 1 to 5 was developed and used, in which $1=$ excellent (no bad seed), $2=\operatorname{good}$ (less than $10 \%$ bad seed), $3=$ fair ( 11 to $30 \%$ bad seed), $4=$ poor (31 to $50 \%$ bad seed), and $5=$ very poor (more than $50 \%$ bad seed). Factors considered in estimating seed quality were seed wrinkling, molding, mottling, and discoloration (17).

Data on total precipitation, number of rainy days, average maximum temperatures, and maximum relative humidity during the soybean growing season were obtained from the Stoneville, MS weather station (http://ext.msstate.edu/anr/drec/stations.cgi?defstation= Stoneville). Weather data were also collected at the weather station at the University of Arkansas, and at the University of Missouri-Fisher Delta Research Center Lee farm, Portageville, MO (http://agEBB.missouri.edu).

Data analyses. Analysis of variance (ANOVA) was performed using the Generalized Linear Mixed procedure (PROC GLMMIX) of SAS (version 9.4; SAS Institute) with a poisson distribution and a log link function specified for Phomopsis seed infection. Initial analysis was conducted on the data for each MG in each location (25). Data were combined over locations and further analyzed (i) to test whether there was interaction between entry and location when "location" was the fixed effect and (ii) to compare entries within a location, in which location was the random effect and the entry was the fix effect. For the trials with inoculation treatments in 2010, 2011, and 2012, data were also analyzed for interactions of entries and treatments by years and locations. The entries were compared with Fisher's least significant difference at $P \leq 0.05$. The PROC CORR procedure of SAS was used to compute Pearson's correlation coefficients between percent seed infected by $P$. longicolla and germination rate, and between percent seed infection and visual seed quality.

\section{Results}

In 2009, total precipitation during September and October was 42.6, 52.2, and $36.7 \mathrm{~cm}$ in Arkansas, Mississippi, and Missouri, respectively. Frequent rainfall during the late season caused high levels of seed infection by different fungal pathogens, such as Alternaria, Cercospora, and Fusarium spp. and $P$. longicolla. There were significant differences in seed infection by $P$. longicolla among soybean entries. Some entries, such as PI 189891 and PI 417361, had no seed infection, whereas PI 547827 had a level as high as $80 \%$ at Missouri

Table 3. $F$ test for fixed effects from analysis of variance of Phomopsis seed infection from the noninoculated field trials in Arkansas, Mississippi, and Missouri in $2009^{\mathrm{w}}$

\begin{tabular}{|c|c|c|c|c|}
\hline Fixed effects $x$ & Num DF ${ }^{y}$ & Den DF & $\boldsymbol{F}$ & $P \geq F$ \\
\hline \multicolumn{5}{|l|}{ MG III } \\
\hline Location & 2 & 222 & 60.77 & $<0.0001$ \\
\hline Entry & 44 & 222 & 2.28 & $<0.0001$ \\
\hline Location-entry & 44 & 222 & 2.09 & 0.0003 \\
\hline \multicolumn{5}{|l|}{ MG IV } \\
\hline Location & 2 & 8.06 & 5.69 & 0.0288 \\
\hline Entry & 44 & 320 & 17.83 & $<0.0001$ \\
\hline Location-entry & 87 & 320 & 10.14 & $<0.0001$ \\
\hline \multicolumn{5}{|l|}{ MG V } \\
\hline Location & 2 & 8.10 & 22.78 & 0.0005 \\
\hline Entry & 44 & 330 & 8.65 & $<0.0001$ \\
\hline Location-entry & 77 & 330 & 10.4 & $<0.0001$ \\
\hline
\end{tabular}

w Analysis of variance was performed using the Generalized Linear Mixed model (PROC GLMMIX) of SAS (version 9.4; SAS Institute, Cary, NC).

x Source of variance for Phomopsis seed infection. Phomopsis seed infection was calculated as percentage of seed infected by Phomopsis longicolla from the seed plating assays. $\mathrm{MG}=$ maturity group.

y Numerator degree of freedom.

${ }^{z}$ Denominator degree of freedom calculated based on the Kenward and Rogers approximation method (25).
(Fig. 1). Although there was a significant entry-location interaction for PSD (Table 3), some entries with resistant or susceptible responses were consistent across locations. For example, IA 3001 had susceptible reactions while PI 89891 had resistant reactions in all locations (Fig. 1).

For the tests of 42 selected entries (14 each from MG III, IV, and V) in Arkansas, Mississippi, and Missouri in 2010, 2011, and 2012, field trials were conducted to reevaluate those entries with

Table 4. Analysis of variance of Phomopsis seed infection from the field trials with inoculation treatments in Arkansas, Mississippi, and Missouri in 2010, 2011 , and $2012^{\mathrm{w}}$

\begin{tabular}{|c|c|c|c|c|}
\hline Source of variance $\mathrm{x}$ & Num DFy & Den DFz & $\boldsymbol{F}$ & $P \geq F$ \\
\hline \multicolumn{5}{|l|}{ MG III } \\
\hline Entry & 13 & 615 & 4.70 & $<0.0001$ \\
\hline Location & 2 & 59 & 20.70 & $<0.0001$ \\
\hline Year & 2 & 51 & 52.97 & $<0.0001$ \\
\hline Treatment & 1 & 58 & 6.25 & 0.0153 \\
\hline Entry-location & 26 & 615 & 2.43 & 0.0001 \\
\hline Entry-year & 26 & 615 & 2.82 & $<0.0001$ \\
\hline Entry-treatment & 13 & 615 & 0.74 & 0.723 \\
\hline Entry-location-year & 37 & 615 & 3.86 & $<0.0001$ \\
\hline Entry-treatment-location & 26 & 615 & 1.03 & 0.4307 \\
\hline Entry-treatment-year & 26 & 615 & 1.59 & 0.0333 \\
\hline Entry-treatment-location-year & 26 & 615 & 1.96 & 0.0033 \\
\hline Location-year & 3 & 54 & 82.59 & $<0.0001$ \\
\hline Treatment-location & 2 & 60 & 3.09 & 0.0526 \\
\hline Treatment-year & 2 & 47 & 2.54 & 0.0892 \\
\hline Treatment-location-year & 2 & 47 & 0.26 & 0.7757 \\
\hline \multicolumn{5}{|l|}{ MG IV } \\
\hline Entry & 13 & 597 & 4.05 & $<0.0001$ \\
\hline Location & 2 & 66 & 20.44 & $<0.0001$ \\
\hline Year & 2 & 59 & 75.91 & $<0.0001$ \\
\hline Treatment & 1 & 75 & 14.69 & 0.0003 \\
\hline Entry-location & 26 & 597 & 1.41 & 0.0861 \\
\hline Entry-year & 26 & 597 & 6.20 & $<0.0001$ \\
\hline Entry-treatment & 13 & 597 & 0.51 & 0.9205 \\
\hline Entry-location-year & 37 & 597 & 2.90 & $<0.0001$ \\
\hline Entry-treatment-location & 26 & 597 & 0.76 & 0.801 \\
\hline Entry-treatment-year & 26 & 597 & 1.38 & 0.1026 \\
\hline Entry-treatment-location-year & 25 & 597 & 2.06 & 0.0019 \\
\hline Location-year & 3 & 65 & 89.62 & $<0.0001$ \\
\hline Treatment-location & 2 & 76 & 11.25 & $<0.0001$ \\
\hline Treatment-year & 2 & 50 & 2.41 & 0.1002 \\
\hline Treatment-location-year & 2 & 50 & 2.26 & 0.1148 \\
\hline \multicolumn{5}{|l|}{ MG V } \\
\hline Entry & 13 & 613 & 3.34 & $<0.0001$ \\
\hline Location & 2 & 85 & 4.16 & 0.0189 \\
\hline Year & 2 & 60 & 206.30 & $<0.0001$ \\
\hline Treatment & 1 & 80 & 9.08 & 0.0035 \\
\hline Entry-location & 25 & 613 & 1.99 & 0.003 \\
\hline Entry-year & 26 & 613 & 4.08 & $<0.0001$ \\
\hline Entry-treatment & 13 & 613 & 0.53 & 0.908 \\
\hline Entry-location-year & 37 & 613 & 1.44 & 0.0455 \\
\hline Entry-treatment-location & 25 & 613 & 0.49 & 0.9837 \\
\hline Entry-treatment-year & 26 & 613 & 0.58 & 0.9535 \\
\hline Entry-treatment-location-year & 26 & 613 & 0.81 & 0.7351 \\
\hline Location-year & 3 & 72 & 33.21 & $<0.0001$ \\
\hline Treatment-location & 2 & 88 & 8.09 & 0.0006 \\
\hline Treatment-year & 2 & 57 & 2.39 & 0.101 \\
\hline Treatment-location-year & 2 & 57 & 4.80 & 0.0118 \\
\hline
\end{tabular}

${ }^{w}$ Analysis of variance was performed using Generalized Linear Mixed model (PROC GLMMIX) of SAS (version 9.4; SAS Institute, Cary, $\mathrm{NC})$

x Source of variance for Phomopsis seed infection. Phomopsis seed infection was calculated as percentage of seed infected by Phomopsis longicolla from the seed plating assays. $\mathrm{MG}=$ maturity group.

y Numerator degree of freedom.

${ }^{\mathrm{z}}$ Denominator degree of freedom calculated based on the Kenward and Rogers approximation method (25). 
$P$. longicolla-inoculated and noninoculated treatments. ANOVA of Phomopsis seed infection indicated that there were significant differences $(P \leq 0.05)$ in entries, inoculation treatments, years, and locations. There also were interactions of location-year, treatment-location, treatment-year, treatment-location-year, entrylocation, entry-year, and entry-location-year (Table 4). However, the variances for these interactions were generally small to minimum in magnitude in relevance to the error term. Therefore, comparison among genotypes and between treatments across locations and years was still valid and meaningful.

Due to hot and dry weather in 2010, the overall percentage of Phomopsis seed infection was much lower than that in 2009 in Missouri (1\%) and Mississippi (2\%). However, seed infection was higher in Arkansas, ranging from 4.3 to 18.5, 0.6 to 20.8, and 0.0 to $9.8 \%$ for MG III, IV, and V, respectively (Tables 5, 6 , and 7). In 2011, hot and dry weather, especially during the

Table 5. Means of percent seed infected by Phomopsis longicolla of 14 maturity group (MG) III soybean entries in replicated field tests with inoculated and noninoculated treatments in Arkansas (AR) and Mississippi (MS) in 2009 and 2012, Missouri (MO) in 2009, and AR in 2010w

\begin{tabular}{|c|c|c|c|c|c|c|c|c|c|}
\hline \multirow[b]{3}{*}{ Entry } & \multirow[b]{3}{*}{ Origin } & \multicolumn{3}{|c|}{2009} & \multirow{3}{*}{$\frac{2010}{\mathrm{AR}} \frac{\operatorname{Inoc} \operatorname{Non}^{x}}{}$} & \multicolumn{4}{|c|}{2012} \\
\hline & & \multirow{2}{*}{$\begin{array}{c}\text { AR } \\
\text { Non }\end{array}$} & \multirow{2}{*}{$\begin{array}{c}\text { MS } \\
\text { Non }\end{array}$} & \multirow{2}{*}{$\begin{array}{l}\text { MO } \\
\text { Non }\end{array}$} & & \multicolumn{2}{|c|}{ AR } & \multicolumn{2}{|c|}{ MS } \\
\hline & & & & & & Non & Inoc & Non & Inoc \\
\hline PI 189891 & France & $8.2 \mathrm{c}$ & $3.5 \mathrm{~cd}$ & $0.0 \mathrm{~d}$ & $8.4 \mathrm{de}$ & $0.5 \mathrm{~cd}$ & $1.5 \mathrm{bc}$ & $11.3 \mathrm{bcd}$ & $13.0 \mathrm{de}$ \\
\hline PI 398697 & South Korea & $9.2 \mathrm{bc}$ & $1.5 \mathrm{~d}$ & $2.0 \mathrm{~d}$ & 10.9 cde & $4.5 \mathrm{ab}$ & $4.5 \mathrm{ab}$ & $22.0 \mathrm{~b}$ & $16.0 \mathrm{de}$ \\
\hline PI 398752 & South Korea & $7.7 \mathrm{c}$ & $2.5 \mathrm{~cd}$ & $2.0 \mathrm{~d}$ & $18.5 \mathrm{a}$ & $0 \mathrm{~d}$ & $2.0 \mathrm{bc}$ & $13.0 \mathrm{bcd}$ & $45.0 \mathrm{bc}$ \\
\hline PI 417361 & Japan & $8.7 \mathrm{bc}$ & $1.5 \mathrm{~d}$ & $0.0 \mathrm{~d}$ & $11.9 \mathrm{bcd}$ & $0 \mathrm{~d}$ & $2.0 \mathrm{bc}$ & $9.0 \mathrm{bcd}$ & $10.0 \mathrm{e}$ \\
\hline PI 437482 & Russia & $8.7 \mathrm{bc}$ & $1.5 \mathrm{~d}$ & $2.0 \mathrm{~d}$ & $10.3 \mathrm{cde}$ & $0.5 \mathrm{~cd}$ & $0 \mathrm{c}$ & $2.7 \mathrm{~d}$ & $78.0 \mathrm{a}$ \\
\hline PI 504481 & Taiwan & $9.0 \mathrm{bc}$ & $1.5 \mathrm{~d}$ & $0.7 \mathrm{~d}$ & $14.4 \mathrm{~b}$ & $1.5 \mathrm{bcd}$ & $3.5 \mathrm{ab}$ & $6.0 \mathrm{~cd}$ & $15.0 \mathrm{de}$ \\
\hline PI 504488 & Taiwan & $9.2 \mathrm{bc}$ & $3.0 \mathrm{~cd}$ & $2.0 \mathrm{~d}$ & $13.4 \mathrm{bc}$ & $0.5 \mathrm{~cd}$ & $1.5 \mathrm{bc}$ & $13.0 \mathrm{bcd}$ & $17.0 \mathrm{cde}$ \\
\hline PI 88490 & China & $11.0 \mathrm{abc}$ & $3.0 \mathrm{~cd}$ & $2.7 \mathrm{~d}$ & $10.6 \mathrm{cde}$ & $1.5 \mathrm{bcd}$ & $2.0 \mathrm{bc}$ & $6.7 \mathrm{~cd}$ & $26.0 \mathrm{cde}$ \\
\hline PI 416988 & Japan & $5.2 \mathrm{c}$ & $1.8 \mathrm{~cd}$ & $30.0 \mathrm{bc}$ & 7.4 ef & $4.0 \mathrm{abc}$ & $4.0 \mathrm{ab}$ & $8.0 \mathrm{bcd}$ & $65.0 \mathrm{ab}$ \\
\hline PI 547827 & United States & $12.7 \mathrm{abc}$ & $39.5 \mathrm{a}$ & $80.0 \mathrm{a}$ & 9.6 cde & $5.5 \mathrm{a}$ & $5.5 \mathrm{a}$ & $6.0 \mathrm{~cd}$ & $63.0 \mathrm{ab}$ \\
\hline PI 548298y & Canada & $21.7 \mathrm{a}$ & $13.5 \mathrm{bc}$ & $12.7 \mathrm{~cd}$ & $18.4 \mathrm{a}$ & $5.5 \mathrm{a}$ & $3.0 \mathrm{abc}$ & $37.0 \mathrm{a}$ & $40.0 \mathrm{bcd}$ \\
\hline PI 578486 & India & $9.7 \mathrm{bc}$ & $21.5 \mathrm{~b}$ & SNA & $4.3 \mathrm{f}$ & $2.0 \mathrm{abcd}$ & $4.0 \mathrm{ab}$ & $12.0 \mathrm{bcd}$ & $77.0 \mathrm{a}$ \\
\hline IA $3001^{y}$ & United States & $20.0 \mathrm{ab}$ & $7.0 \mathrm{~cd}$ & $41.0 \mathrm{~b}$ & $12.4 \mathrm{bc}$ & $0.5 \mathrm{~cd}$ & $2.0 \mathrm{bc}$ & $15.0 \mathrm{bc}$ & 20.0 cde \\
\hline AG $4403^{z}$ & United States & $11.7 \mathrm{abc}$ & $8.0 \mathrm{~cd}$ & $26.0 \mathrm{bcd}$ & $13.4 \mathrm{bc}$ & $0 \mathrm{~d}$ & $2.0 \mathrm{bc}$ & $18.0 \mathrm{bc}$ & 23.0 cde \\
\hline Mean & $\ldots$ & 10.9 & 7.8 & 16.3 & 11.7 & 1.9 & 2.7 & 12.8 & 36.3 \\
\hline
\end{tabular}

w Tests at MO and MS in 2010 and at all locations in 2011 were not included because disease pressure was below $5 \%$ and that was not enough disease to adequately compare entries. Non $=$ noninoculated control sprayed with distilled water and Inoc $=$ inoculated with spore suspension of $P$. longicolla $\left(2 \times 10^{5}\right)$ at the R5 stage. Numbers followed by the same letter within a column are not significant different by the least significant difference test at $P \leq 0.05$; SNA $=$ seed was not available.

x Means across inoculation treatments.

y Susceptible check.

${ }^{z}$ Resistant check, MG IV.

Table 6. Means of percent seed infected by Phomopsis longicolla of 14 maturity group IV soybean entries in replicated field tests with inoculated and noninoculated treatments in Arkansas (AR) and Mississippi (MS) in 2009 and 2012, Missouri (MO) in 2009, and AR in 2010w

\begin{tabular}{|c|c|c|c|c|c|c|c|c|c|}
\hline \multirow[b]{3}{*}{ Entry } & \multirow[b]{3}{*}{ Origin } & \multicolumn{3}{|c|}{2009} & \multirow{3}{*}{$\frac{2010}{\mathrm{AR}} \frac{\operatorname{Inoc}_{\mathrm{Non}} \mathrm{x}}{}$} & \multicolumn{4}{|c|}{2012} \\
\hline & & \multirow{2}{*}{$\begin{array}{c}\text { AR } \\
\text { Non }\end{array}$} & \multirow{2}{*}{$\begin{array}{c}\text { MS } \\
\text { Non }\end{array}$} & \multirow{2}{*}{$\begin{array}{l}\text { MO } \\
\text { Non }\end{array}$} & & \multicolumn{2}{|c|}{$\mathbf{A R}$} & \multicolumn{2}{|c|}{ MS } \\
\hline & & & & & & Non & Inoc & Non & Inoc \\
\hline PI 158765 & China & $18.5 \mathrm{abcd}$ & $6.5 \mathrm{ef}$ & $2.0 \mathrm{e}$ & $20.8 \mathrm{a}$ & $0.5 \mathrm{c}$ & $1.0 \mathrm{~b}$ & $2.0 \mathrm{de}$ & $21.5 \mathrm{def}$ \\
\hline PI 235335 & Uruguay & $19.0 \mathrm{abcd}$ & $0.0 \mathrm{f}$ & $0.0 \mathrm{e}$ & $19.6 \mathrm{ab}$ & $0.5 \mathrm{c}$ & $0.5 \mathrm{~b}$ & $6.0 \mathrm{cde}$ & $19.0 \mathrm{ef}$ \\
\hline PI 235346 & Uruguay & $14.0 \mathrm{bcd}$ & $4.5 \mathrm{ef}$ & $8.0 \mathrm{e}$ & $7.6 \mathrm{~d}$ & $4.0 \mathrm{abc}$ & $16.5 \mathrm{a}$ & $4.0 \mathrm{de}$ & $49.0 \mathrm{~b}$ \\
\hline PI 346307 & India & $24.0 \mathrm{abc}$ & $1.5 \mathrm{f}$ & $2.0 \mathrm{e}$ & $15.0 \mathrm{c}$ & $2.0 \mathrm{bc}$ & $5.0 \mathrm{ab}$ & $12.0 \mathrm{abcd}$ & $45.0 \mathrm{bc}$ \\
\hline PI 346308 & India & $20.7 \mathrm{~cd}$ & $1.0 \mathrm{f}$ & $0.0 \mathrm{e}$ & $15.6 \mathrm{c}$ & $1.0 \mathrm{c}$ & $1.0 \mathrm{~b}$ & $6.0 \mathrm{cde}$ & 15.0 ef \\
\hline PI 416779 & Japan & $16.5 \mathrm{bcd}$ & $0.0 \mathrm{f}$ & $0.0 \mathrm{e}$ & $12.9 \mathrm{c}$ & $1.5 \mathrm{c}$ & $5.5 \mathrm{ab}$ & $3.0 \mathrm{de}$ & $2.0 \mathrm{f}$ \\
\hline PI 80479 & Japan & $28.0 \mathrm{ab}$ & $28.0 \mathrm{ef}$ & $2.7 \mathrm{e}$ & $1.3 \mathrm{e}$ & $9.5 \mathrm{ab}$ & $7.5 \mathrm{ab}$ & $19.0 \mathrm{a}$ & $85.0 \mathrm{a}$ \\
\hline PI 87074 & South Korea & $13.3 \mathrm{bcd}$ & $9.5 \mathrm{ef}$ & $6.0 \mathrm{e}$ & $8.5 \mathrm{~d}$ & $5.0 \mathrm{abc}$ & $6.0 \mathrm{ab}$ & $18.0 \mathrm{ab}$ & 20.0 ef \\
\hline PI 264555 & Argentina & $25.3 \mathrm{abc}$ & $52.0 \mathrm{~b}$ & $35.3 \mathrm{~d}$ & $0.6 \mathrm{e}$ & $6.5 \mathrm{abc}$ & $3.5 \mathrm{~b}$ & $0.0 \mathrm{e}$ & $11.0 \mathrm{ef}$ \\
\hline PI 355070 & United States & $6.5 \mathrm{~d}$ & $43.5 \mathrm{bc}$ & $44.0 \mathrm{~cd}$ & $6.0 \mathrm{~d}$ & $11.5 \mathrm{a}$ & $10.5 \mathrm{ab}$ & $11.0 \mathrm{abcd}$ & $61.0 \mathrm{~b}$ \\
\hline PI $371611^{y}$ & Pakistan & $33.0 \mathrm{a}$ & $73.0 \mathrm{a}$ & $65.0 \mathrm{ab}$ & $16.3 \mathrm{bc}$ & $7.5 \mathrm{abc}$ & $4.5 \mathrm{ab}$ & $16.0 \mathrm{abc}$ & $41.0 \mathrm{bcd}$ \\
\hline PI 404173 & China & $20.5 \mathrm{abcd}$ & $71.0 \mathrm{a}$ & $74.7 \mathrm{a}$ & $16.1 \mathrm{bc}$ & $11.0 \mathrm{a}$ & $3.0 \mathrm{~b}$ & 8.0 bcde & $46.0 \mathrm{~b}$ \\
\hline AP $350^{y}$ & United States & $11.5 \mathrm{~cd}$ & $33.5 \mathrm{~cd}$ & $56.0 \mathrm{bc}$ & $9.1 \mathrm{~d}$ & $1.0 \mathrm{c}$ & $1.0 \mathrm{~b}$ & $2.0 \mathrm{de}$ & 24.0 cde \\
\hline SUWEON97z & South Korea & $12.0 \mathrm{~cd}$ & $19.5 \mathrm{de}$ & $2.0 \mathrm{e}$ & 8.4.d & $5.0 \mathrm{abc}$ & $3.5 \mathrm{~b}$ & $11.0 \mathrm{abcd}$ & $23.0 \mathrm{de}$ \\
\hline Mean & $\ldots$ & 18.7 & 24.5 & 24.9 & 11.3 & 4.8 & 4.9 & 8.4 & 33.0 \\
\hline
\end{tabular}

w Tests at MO and MS in 2010 and at all locations in 2011 were not included because disease pressure was below $5 \%$ and that was not enough disease to adequately compare entries. Non $=$ noninoculated control sprayed with distilled water and Inoc $=$ inoculated with spore suspension of $P$. longicolla $\left(2 \times 10^{5}\right)$ at the R5 stage. Numbers followed by the same letter within a column are not significant different by the least significant difference test at $P \leq 0.05$

x Means across inoculation treatments.

y Susceptible check.

${ }^{\mathrm{z}}$ Cultivar check. 
period from the pod fill through harvest stages, caused almost no seed infection. The ranges of percent Phomopsis seed infection were 0 to 5,0 to 2.6, and 0 to $1.5 \%$ in Arkansas, Mississippi, and Missouri, respectively. There was no significant $(P \leq 0.05)$ difference in Phomopsis seed infection between inoculated and noninoculated treatments in the hot and dry environment in 2010 and 2011.

In 2012, harvest was delayed 10 to 20 days due to frequent rainfall, which favored disease development. Significant differences in seed infection by $P$. longicolla were observed among soybean entries, with ranges of 0.5 to 16.5 and 2.7 to $85 \%$ in Arkansas and Mississippi, respectively (Tables 5, 6, and 7), in which most genotypes showing consistent seed infection by $P$. longicolla and ranking in the tests. For example, in Mississippi, percent seed infected by $P$. longicolla in PI 417361 was significantly $(P \leq 0.05)$ lower than that of the susceptible check (Table 5). It had 9 and $10 \%$ seed infection compared with 15 and $20 \%$ seed infection in IA 3001, and 37 and $40 \%$ seed infection in PI 548298, in noninoculated and inoculated trials, respectively, in 2012 (Table 5). In the tests of MG IV soybeans, PI 416779 had $2.0 \%$ seed infection in the inoculated trial in Mississippi, which was significantly $(P \leq 0.05)$ lower than $24 \%$ of the susceptible check (AP 350) in 2012 (Table 6). In the tests of MG V soybeans, PI 381659 and PI 4174567 had significantly $(P \leq 0.05)$ lower seed infection than both resistant and cultivar checks in noninoculated and inoculated trials (Table 7). However, occasionally, the same soybean genotype had different reactions to $P$. longicolla in different years or different inoculation treatments. PI 437482 had a resistant reaction in Mississippi in 2009 and 2012 by natural infection with 1.5 and $2.7 \%$ seed infected by $P$. longicolla, respectively, but it had the most susceptible reaction, with $78 \%$ seed infection, in inoculated treatment in 2012 (Table 5).

Results of 2009 and 2012 in Arkansas, Missouri, and Mississippi and 2010 in Arkansas for MG III, MG IV, and MG V are summarized in Tables 5, 6, and 7. Because seed infected by $P$. longicolla was below 5\% and that was not enough disease pressure to adequately compare entries at Missouri and Mississippi locations in 2010 or all three locations in 2011, seed assay data were not presented in those tables. Six MG III (PI 189891, PI 398697, PI 417361, PI 504481, PI 504488, and PI 88490), four MG IV (PI 158765, PI 235335, PI 346308, and PI 416779), and five MG V (PI 381659, PI 381668, PI 407749, PI 417567, and PI 476920) had significantly $(P \leq 0.05)$ lower percent seed infected by $P$. longicolla than the susceptible checks and other lines in the same test.

The differences among entries were also found in seed germination rate and visual scores of seed quality (Table 8). In 2009, PI 548298, a susceptible check, had germination rates of 54 to $70 \%$, whereas PI 398697, a resistant line, had higher germination rates of 77 to $99 \%$. In addition, inoculation treatments reduced germination rate in most lines. For example, in 2012, PI 89891 had a $91 \%$ germination rate in the noninoculated trial but had only $48 \%$ germination rate in the inoculated trial (Table 8). However, in some cases, inoculation treatment did not reduce the germinate rate in some lines. For example, in 2012, PI 398697 had 95.8 and $95.3 \%$ germination rates in the noninoculated and inoculated trials, respectively, in Mississippi; and PI 381688 had 91.0 and $91.5 \%$ germination rate in the noninoculated and inoculated trials, respectively, in Arkansas (Table 8). In general, percent seed infected by $P$. longicolla was negatively correlated with germination rate but positively correlated with visual quality (Table 9).

\section{Discussion}

Of the 135 lines tested, 15 accessions (6 MG III, 4 MG IV, and 5 MG V) had significantly $(P \leq 0.05)$ lower Phomopsis seed infection than the susceptible checks across years and locations. These lines were PI 189891, PI 398697, PI 417361, PI 504481, PI 504488, and PI 88490 in MG III; PI 158765, PI 235335, PI 346308, and PI 416779 in MG IV; and PI 381659, PI 381668, PI 407749, PI 417567, and PI 476920 in MG V. These resistant lines are in addition to what was previously reported. A 3-year study from 1983 to 1985 in Missouri and Puerto Rico identified PI 417479 as resistant (4), and eight resistant MG V accessions were identified in a 4-year study from 2006 to 2009 at Stoneville, MS (23).

Table 7. Means of percent seed infected by Phomopsis longicolla of 14 maturity group V soybean entries in replicated field tests with inoculated and noninoculated treatments in Arkansas (AR), Mississippi (MS) in 2009 and 2012, Missouri (MO) in 2009, and AR in 2010

\begin{tabular}{|c|c|c|c|c|c|c|c|c|c|}
\hline \multirow[b]{3}{*}{ Entry } & \multirow[b]{3}{*}{ Origin } & \multicolumn{3}{|c|}{2009} & \multirow{3}{*}{$\frac{2010}{\frac{A R}{\text { Inoc/Non }^{w}}}$} & \multicolumn{4}{|c|}{2012} \\
\hline & & \multirow{2}{*}{$\begin{array}{c}\mathbf{A R} \\
\text { Non }\end{array}$} & \multirow{2}{*}{$\begin{array}{l}\text { MS } \\
\text { Non }\end{array}$} & \multirow{2}{*}{$\begin{array}{l}\text { MO } \\
\text { Non }\end{array}$} & & \multicolumn{2}{|c|}{$\mathbf{A R}$} & \multicolumn{2}{|c|}{ MS } \\
\hline & & & & & & Non & Inoc & Non & Inoc \\
\hline PI 506844 & Japan & $9.0 \mathrm{bc}$ & $41.0 \mathrm{e}$ & $39.7 \mathrm{e}$ & $1.1 \mathrm{~cd}$ & $7.0 \mathrm{bc}$ & $4.5 \mathrm{abc}$ & $13.0 \mathrm{a}$ & $47.0 \mathrm{a}$ \\
\hline PI 381659 & Uganda & $13.5 \mathrm{abc}$ & $2.0 \mathrm{~g}$ & $40.7 \mathrm{e}$ & $1.6 \mathrm{bcd}$ & $1.0 \mathrm{e}$ & $2.0 \mathrm{bc}$ & $3.0 \mathrm{~d}$ & $1.0 \mathrm{e}$ \\
\hline PI 381668 & Uganda & $14.5 \mathrm{abc}$ & $41.5 \mathrm{e}$ & $14.7 \mathrm{f}$ & $0.1 \mathrm{~d}$ & 3.0 cde & $4.0 \mathrm{bc}$ & $21.0 \mathrm{abc}$ & $18.0 \mathrm{de}$ \\
\hline PI 407749 & China & $13.5 \mathrm{abc}$ & $5.0 \mathrm{~g}$ & SNA & $0.9 \mathrm{~cd}$ & $2.5 \mathrm{~cd}$ & $2.5 \mathrm{bc}$ & $15.0 \mathrm{abc}$ & $27.0 \mathrm{bcd}$ \\
\hline PI 417567 & Taiwan & $27.0 \mathrm{a}$ & $1.0 \mathrm{~g}$ & SNA & $9.8 \mathrm{a}$ & $1.3 \mathrm{de}$ & $2.5 \mathrm{bc}$ & $0.0 \mathrm{~d}$ & $2.0 \mathrm{e}$ \\
\hline PI 471938 & Nepal & $11.0 \mathrm{bc}$ & $57.0 \mathrm{cde}$ & $16.7 \mathrm{f}$ & $0.3 \mathrm{~d}$ & $3.0 \mathrm{cde}$ & $3.0 \mathrm{bc}$ & $4.0 \mathrm{~cd}$ & $16.0 \mathrm{de}$ \\
\hline PI 476920 & Vietnam & $4.0 \mathrm{c}$ & $13.0 \mathrm{fg}$ & $57.7 \mathrm{bc}$ & $0.8 \mathrm{~cd}$ & 2.7 cde & $1.5 \mathrm{c}$ & $4.0 \mathrm{bcd}$ & $26.0 \mathrm{bcd}$ \\
\hline PI 507690 & Russia & $9.5 \mathrm{bc}$ & $22.0 \mathrm{f}$ & $44.3 \mathrm{de}$ & $1.9 \mathrm{bcd}$ & $15.0 \mathrm{a}$ & $4.5 \mathrm{abc}$ & $7.0 \mathrm{ab}$ & $53.0 \mathrm{a}$ \\
\hline PI 172902 & Turkey & $3.5 \mathrm{c}$ & $46.0 \mathrm{de}$ & $67.0 \mathrm{ab}$ & $0.0 \mathrm{~d}$ & 2.5 cde & $4.5 \mathrm{abc}$ & $4.0 \mathrm{abc}$ & $38.0 \mathrm{abc}$ \\
\hline PI 407752 & China & $15.5 \mathrm{abc}$ & $80.5 \mathrm{a}$ & $57.0 \mathrm{bcd}$ & $1.4 \mathrm{bcd}$ & $9.5 \mathrm{~b}$ & $8.5 \mathrm{a}$ & $8.0 \mathrm{bcd}$ & $23.0 \mathrm{~cd}$ \\
\hline PI $417420^{x}$ & Japan & $21.0 \mathrm{ab}$ & $64.0 \mathrm{bc}$ & $65.3 \mathrm{ab}$ & $0.1 \mathrm{~d}$ & 4.0 cde & $4.0 \mathrm{bc}$ & $7.0 \mathrm{bc}$ & $37.0 \mathrm{abc}$ \\
\hline PI 417098 & Japan & $20.0 \mathrm{ab}$ & $75.0 \mathrm{ab}$ & $44.3 \mathrm{de}$ & $0.3 \mathrm{~d}$ & 4.0 cde & $2.0 \mathrm{bc}$ & $14.0 \mathrm{bc}$ & $22.0 \mathrm{~cd}$ \\
\hline TARA $^{\mathrm{y}}$ & United States & $19.5 \mathrm{ab}$ & $63.0 \mathrm{bcd}$ & $76.0 \mathrm{a}$ & $3.4 \mathrm{~b}$ & $6.5 \mathrm{bcd}$ & $4.5 \mathrm{abc}$ & $15.0 \mathrm{ab}$ & $42.7 \mathrm{ab}$ \\
\hline $5002 \mathrm{~T}^{\mathrm{z}}$ & United States & $8.5 \mathrm{bc}$ & $17.0 \mathrm{fg}$ & 48.0 cde & $2.4 \mathrm{bc}$ & $6.0 \mathrm{bcde}$ & $6.0 \mathrm{ab}$ & $2.0 \mathrm{~cd}$ & $12.0 \mathrm{de}$ \\
\hline Mean & $\ldots$ & 13.6 & 37.7 & 47.6 & 1.7 & 5 & 3.9 & 8.4 & 26 \\
\hline
\end{tabular}

v Tests at MO and MS in 2010 and at all locations in 2011 were not included because disease pressure was below $5 \%$ and that was not enough disease to adequately compare entries. Non $=$ noninoculated control sprayed with distilled water and Inoc $=$ inoculated with spore suspension of $P$. longicolla $\left(2 \times 10^{5}\right)$ at the R5 stage. Numbers followed by the same letter within a column are not significant different by the least significant difference test at $P \leq 0.05$; SNA $=$ seed was not available.

w Means across inoculation treatments.

x Susceptible check.

y Resistant check.

${ }^{\mathrm{z}}$ Cultivar check. 
In the current study, there were interactions with location and year. For example, AP 350 was a susceptible check for the tests of MG IV entries and was used as a susceptible parent to develop populations for inheritance studies and genetic mapping $(12,13)$. This cultivar was rated as susceptible in all three states in 2009 but resistant in 2012 in Arkansas. Likewise, PI 80479 was rated as resistant in Missouri in 2009 but as susceptible in all years in Arkansas and Mississippi. It is not known whether these differences in cultivar reaction were due to pathogen diversity, differences in environmental conditions, or both. High seed infection was associated with years and locations that had high rainfall. This is consistent with previous reports that rain from R7 until

Table 8. Means of germination rate of soybean entries and visual quality in replicated field tests in Arkansas (AR), Mississippi (MS), and Missouri (MO)y

\begin{tabular}{|c|c|c|c|c|c|c|c|c|c|c|c|c|c|c|c|c|c|c|c|}
\hline \multirow[b]{3}{*}{ Entry $^{z}$} & \multirow[b]{3}{*}{ MG } & \multicolumn{6}{|c|}{2009} & \multirow{2}{*}{\multicolumn{4}{|c|}{$\frac{2010}{A R}$}} & \multicolumn{8}{|c|}{2012} \\
\hline & & \multicolumn{2}{|c|}{$\mathbf{A R}$} & \multicolumn{2}{|c|}{ MO } & \multicolumn{2}{|c|}{ MS } & & & & & \multicolumn{4}{|c|}{$A R$} & \multicolumn{4}{|c|}{ MS } \\
\hline & & $\overline{\text { GM }}$ & $\overline{\text { VQ }}$ & GM & $\overline{\mathrm{VQ}}$ & SM & $\overline{\text { VQ }}$ & SM & $\mathbf{Q}$ & GM1 & $\overline{\text { VQ1 }}$ & GM & VQ & GM1 & $\overline{\mathrm{VQ1}}$ & $\mathbf{M}$ & VQ & GM1 & $\overline{Q 1}$ \\
\hline PI189891 & III & 63.0 & 4.3 & 51.3 & 2.7 & 34.6 & 2.3 & 21.0 & 5.0 & 15.0 & 5.0 & 72.0 & 3.5 & 71.0 & 4.0 & 91.3 & 2.5 & 48.0 & 2.9 \\
\hline PI398697 & III & 7.0 & 3.7 & 96.7 & 1.0 & 99.0 & 1.3 & 22.6 & 4.5 & 31.0 & 5.0 & 57.3 & 4.3 & 19.8 & 4.8 & 5.8 & 1.3 & 95.3 & 1.9 \\
\hline PI398752 & III & 7.0 & 3.7 & 87.3 & 1.5 & 88.9 & 1.5 & 16.5 & 4.5 & 6.5 & 4.8 & 38.0 & 3.0 & 42.0 & 4.3 & 6.3 & 1.6 & 87.3 & 2.1 \\
\hline PI417361 & III & 8.5 & 3.0 & 93.3 & 1.0 & 79.0 & 1.3 & 19.3 & 3.0 & 22.7 & 4.3 & 77.5 & 3.0 & 58.0 & 2.8 & 9.3 & 1.3 & 93.5 & 1.5 \\
\hline PI437482 & III & 1.0 & 2.7 & 58.0 & 1.3 & 59.4 & 1.6 & 53.5 & 3.0 & 41.5 & 3.3 & 37.5 & 2.8 & 36.0 & 2.5 & 95.8 & 1.8 & 72.7 & 2.9 \\
\hline PI504481 & III & 86.5 & 3.3 & 88.0 & 1.7 & 87.5 & 1.6 & 13.0 & 4.3 & 15.0 & 5.0 & 72.0 & 3.5 & 69.5 & 3.5 & 92.8 & 1.6 & 76.8 & 2.3 \\
\hline PI504488 & III & 79.0 & 3.0 & 94.0 & 1.0 & 59.5 & 1.5 & 34.0 & 3.0 & 27.5 & 3.5 & 79.0 & 2.8 & 77.5 & 2.3 & 95.8 & 1.5 & 91.5 & 2.0 \\
\hline PI88490 & III & 53.0 & 3.0 & 90.0 & 2.0 & 81.0 & 1.8 & 27.6 & 4.0 & 23.5 & 5.0 & 77.5 & 2.8 & 80.0 & 1.8 & 85.3 & 3.2 & 83.0 & 3.5 \\
\hline PI416988 & III & 75.0 & 4.0 & 87.3 & 3.0 & 95.3 & 1.8 & & 2.8 & 73.0 & 3. & 78.0 & 33 & & & & 1.8 & & 2.4 \\
\hline PI547827 & III & 74.0 & 4.3 & 62.7 & 1.0 & 75.3 & 1.8 & & 3.3 & 39.0 & 4. & 54.5 & 3.0 & 53.0 & 3.8 & 2.0 & 2.0 & & .3 \\
\hline PI548298 & III & 4.0 & 4.0 & 70.0 & 1.7 & 63.5 & 1.8 & 5.5 & 5.0 & 9.1 & 5.0 & 59.5 & 3.3 & 43.0 & 4.0 & 8.3 & 3.4 & 69.0 & 3.3 \\
\hline PI578486 & III & .7 & 4.0 & SNA & SNA & 45.1 & 2.2 & 53.0 & 4.0 & 67.0 & 4. & 76.0 & 2.8 & 75.5 & 1.8 & 7.8 & 2.3 & 70.8 & 2.5 \\
\hline AG4403 & III & 3.0 & 5.0 & 93.3 & 1.7 & 58.4 & 2.3 & 36.5 & 4.5 & 20.5 & 5 & 60.3 & 3.8 & 59.0 & 4.0 & 9.3 & 3.6 & 78.3 & 3.4 \\
\hline IA3001 & III & 54.0 & 4.7 & 82.7 & 2.0 & 89.0 & 1.4 & 29.0 & 5.0 & 35.0 & 4 & 67.0 & 3.8 & 56.0 & 3.8 & 3.8 & 1.9 & 78.3 & 2.9 \\
\hline Mean & $\ldots$ & 70.0 & 3.7 & 81.1 & 1.7 & 72.5 & 1.7 & 32.0 & 4.0 & 30.5 & 4. & 64.7 & 3.2 & 56.9 & 3.3 & 88.1 & 2.1 & 7.6 & 2.6 \\
\hline LSD & $\ldots$ & 35.9 & 1.5 & 14.2 & 1.0 & 27.9 & 1.5 & 13.8 & 0.8 & 16.8 & 0.7 & 14.7 & 1.2 & 15.5 & 1.0 & 3.1 & 0.9 & 18.6 & 0.7 \\
\hline PI158765 & IV & 74.0 & 4.3 & 85.0 & 1.0 & 91.0 & 2.3 & 12.7 & 5.0 & 4.1 & 5.0 & 53.5 & 3.8 & 56.0 & 3.8 & 3.8 & 3.3 & 85.5 & 3.1 \\
\hline PI235. & IV & 43.0 & 4.8 & 93.3 & 1.0 & 51.0 & 2.6 & 8.0 & 5.0 & 9.5 & 5.0 & 54.3 & 4.5 & 66.0 & 4.5 & 9.0 & 1.6 & 76.8 & 1.5 \\
\hline PI235346 & IV & 80.0 & 4.3 & 92.0 & 2.0 & 74.3 & 2.5 & 44.0 & 4.5 & 30.0 & 5.0 & 64.0 & 4.0 & 70.5 & 4.0 & 84.3 & 2.6 & 56.0 & 2.0 \\
\hline PI346307 & IV & 69.5 & 5.0 & 58.3 & 1.3 & 72.0 & 3.0 & 44.5 & 5.0 & 26.5 & 5.0 & 89.0 & 3.5 & 76.3 & 3.8 & 0.5 & 2.8 & 70.0 & 2.9 \\
\hline PI346308 & IV & & 4.3 & 77.3 & 2. & & 3.0 & & 2.3 & 60.5 & & & 3.3 & & & & & & 1.9 \\
\hline PI416779 & IV & 57.0 & 4.3 & 56.0 & 2. & & 2. & & 4.5 & 29. & & 69.0 & 3.0 & 58.0 & & 3 & 2.8 & & 2.9 \\
\hline PI80479 & IV & 54.0 & 4. & 89.3 & 1. & & 3. & 8 & 2. & 84. & & 72.5 & 1.8 & 59 & & 0 & 3.3 & & 3.8 \\
\hline PI87 & IV & .7 & 3. & 68.7 & 1. & & 2 & 37.0 & 5.0 & 40. & 5 & 72.0 & 3.3 & 73.5 & 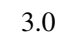 & 0 & 2.8 & 3 & 3.5 \\
\hline PI26 & IV & 3.0 & 3.7 & 73.3 & 1.0 & 35.0 & 3.4 & 88.0 & 2.0 & 85.0 & 1. & 73.5 & 2.0 & 73.5 & 3.5 & 75.0 & 1.8 & 0 & 3.4 \\
\hline 70 & IV & 77.5 & 3.8 & 73.7 & 2.7 & 45.5 & 3. & 57.0 & 3.3 & 66.5 & 3. & 79.5 & 3.3 & 84.0 & 4.3 & 7.0 & 2.4 & 60.8 & 3.0 \\
\hline PI371611 & IV & 60.5 & 4.3 & 49.3 & 2.7 & 20.8 & 3.3 & 43.5 & 2.8 & 41.0 & 3. & 86.5 & 2.5 & 84.0 & 3.0 & 6.8 & 3.1 & 55.5 & 3.3 \\
\hline PI404173 & IV & 87.5 & 4.0 & 23.3 & 1.0 & 37.5 & 2.8 & 48.5 & 2.3 & 47.5 & 2.5 & 72.5 & 2.0 & 74.5 & 1.8 & 8.8 & 2.4 & 70.3 & 2.5 \\
\hline SUWEON97 & IV & 62.0 & 4.3 & SNA & SNA & 67.5 & 2.9 & 56.7 & 4.5 & 56.5 & 4.5 & 70.5 & 3.8 & 67.5 & 3.8 & 71.8 & 3.6 & 78.8 & 3.1 \\
\hline AP350 & IV & 86.7 & 4.5 & 58.3 & 1.7 & 1.5 & 3.3 & 44.5 & 5.0 & 41.0 & 4.8 & 60.0 & 4.5 & 66.5 & 4.8 & 92.5 & 2.5 & 77.3 & 3.0 \\
\hline Mean & $\ldots$ & 69.6 & 4.3 & 69.1 & 1. & 55.4 & 2.9 & 47.3 & 3.8 & 44.4 & 3.8 & 70.1 & 3.2 & 69.7 & 3.3 & 79.0 & 2.7 & 64.9 & 2.8 \\
\hline LSD & & 44.5 & 1.3 & 14.1 & 0.8 & 29.4 & 0.6 & 15.8 & 0.6 & 15.7 & 0.7 & 15.2 & 1.2 & 15.9 & 1.2 & 27.7 & 0.8 & 23.3 & 0.6 \\
\hline PI506 & $\mathrm{V}$ & & 3.0 & 66.0 & 2 & & 3 & & 2. & 84 & & & & & 3.0 & 3 & 2.9 & 6 & 2.6 \\
\hline PI381659 & $\mathrm{V}$ & & 3.0 & 88.0 & 2. & & 2 & & 2.0 & 83 & & & 2.5 & & & 0.0 & 2.6 & 9 & 2.3 \\
\hline PI381668 & $\mathrm{V}$ & 95.0 & 3.3 & 91.0 & 1. & 58.3 & 4. & 97.0 & 1.5 & 91 & 1. & 91.0 & 2.5 & 91.5 & 2.0 & 90.8 & 2.6 & 93.0 & 2.5 \\
\hline PI407749 & V & 5 & 3. & 68.0 & 4.0 & 69.8 & 3. & 94.0 & 1.3 & 95.5 & 2. & 87.0 & 2.8 & 91.5 & 2.3 & 77.8 & 2.9 & 82.5 & 2.6 \\
\hline PI417567 & V & 93.0 & 4.5 & 65.0 & 2.7 & 98.3 & 2.0 & 75.3 & 2.0 & 86.0 & 2.3 & 62.3 & 2.7 & 72.0 & 2.5 & 95.3 & 2.1 & 86.0 & 2.5 \\
\hline PI471938 & V & 97.5 & 3.3 & 75.0 & 1.0 & 16.0 & 3.8 & 88.5 & 2.0 & 87.5 & 2.0 & 84.5 & 2.5 & 85.0 & 2.5 & 93.0 & 2.1 & 93.5 & 2.1 \\
\hline PI476920 & $\mathrm{V}$ & 96.5 & 3.0 & 91.0 & 3.0 & 82.3 & 3.6 & 83.0 & 1.3 & 86.0 & 2.0 & 96.7 & 2.0 & 92.5 & 2.5 & 85.3 & 2.3 & 69.0 & 2.4 \\
\hline PI507690 & $\mathrm{V}$ & 97.5 & 3.0 & 82.0 & 1.0 & 80.0 & 3.3 & 90.0 & 3.0 & 85.0 & 3.5 & 81.0 & 2.5 & 81.3 & 2.3 & 70.8 & 3.4 & 63.8 & 3.0 \\
\hline PI172902 & $\mathrm{V}$ & 98.5 & 3.0 & 95.0 & 1.0 & 43.8 & 3.5 & 90.0 & 1.5 & 96.0 & 1.5 & 84.0 & 2.5 & 88.5 & 2.3 & 88.5 & 2.6 & 78.8 & 3.0 \\
\hline PI407752 & $\mathrm{V}$ & 90.0 & 3.5 & 85.0 & 2.7 & 7.5 & 4.1 & 74.5 & 2.0 & 77.0 & 2.0 & 82.0 & 2.5 & 78.0 & 2.3 & 86.5 & 2.3 & 79.8 & 2.9 \\
\hline PI417420 & $\mathrm{V}$ & 93.5 & 3.3 & 80.0 & 2.3 & 4.3 & 4.9 & 94.5 & 1.5 & 91.5 & 1.5 & 90.5 & 2.3 & 88.0 & 2.8 & 88.0 & 2.5 & 85.3 & 2.5 \\
\hline PI417098 & $\mathrm{V}$ & & 3.5 & 80.0 & 3. & 15.5 & 4.8 & & 1.5 & 93.5 & 1. & 91.5 & 2.5 & 88.5 & 2.0 & 78.8 & 3.1 & 84.3 & 2.9 \\
\hline $5002 \mathrm{~T}$ & V & & 3.0 & & & & 3. & & 4.0 & 76.0 & & & & & & 93.5 & 2.3 & 86.3 & 2.5 \\
\hline TARA & $\mathrm{V}$ & 93.0 & 3.3 & 44.0 & 4.0 & 8.8 & 4.6 & 79.5 & 2.8 & 86.9 & 2.3 & 75.5 & 2.5 & 82.0 & 2.8 & 74.8 & 3.3 & 56.8 & 3.0 \\
\hline Mean & $\ldots$ & 95.6 & 3.3 & 78.3 & 2.4 & 47.0 & 3.8 & 86.9 & 2.1 & 87.1 & 2.2 & 83.9 & 2.5 & 84.2 & 2.5 & 84.1 & 2.6 & 79.7 & 2.6 \\
\hline LSD & $\ldots$ & 7.9 & 1.0 & 12.7 & 1.3 & 27.8 & 0.6 & 11.9 & 1.0 & 10.5 & 0.9 & 9.4 & 1.1 & 9.5 & 0.7 & 12.7 & 0.4 & 13.8 & 0.6 \\
\hline
\end{tabular}

\footnotetext{
$\mathrm{y}$ Tests at MO and MS in 2010 and at all locations in 2011 were not included because disease pressure was below $10 \%$ and that was not enough disease to adequately compare entries. $\mathrm{MG}=$ maturity group, $\mathrm{GM}=$ percentage of seed germination from noninoculated tests, and $\mathrm{VQ}=\mathrm{visual}$ quality from noninoculated tests. Seed were assessed using a scale of 1 to 5 , where $1=$ excellent (no bad seed), $2=\operatorname{good}($ less than $10 \%$ bad seed), $3=$ fair $(11$ to $30 \%$ bad seed), $4=$ poor ( 31 to $50 \%$ bad seed), and $5=$ very poor (more than $50 \%$ bad seed). Factors considered in estimating seed quality were: development of seed wrinkling, molding, mottling, and discoloration. GM1 = percentage of seed germination from inoculated tests. Plants were inoculated with spore suspension of Phomopsis longicolla $\left(2 \times 10^{5}\right)$ at the R5 stage. VQ1 $=$ visual quality from inoculated tests. SNA $=$ seed was not available.
}

${ }^{\mathrm{z}} \mathrm{LSD}=$ Fisher's protected least significant difference test $(P \leq 0.05)$ for means within the column in each maturity group. 
harvest leads to high levels of PSD $(28,33,35,36)$. Rain during this period maintains high pod moisture, allowing greater seed infection $(3,32,33,35,36)$. Temperature is also important. Seed maturing under warm conditions often have higher seed infection than those maturing later in the season under cooler conditions (3133,36). As a result, early-maturing cultivars, especially if planted early, have higher levels of PSD than cultivars in later MG or planted late $(28,40)$. Because early planting of early-maturing cultivars (ESPS planting practice) is common in the South to increase yields and reduce irrigation costs (9), planting PSD-resistant cultivars under these conditions is particularly important to preserve seed quality and reduce yield losses due to $\mathrm{PSD}$.

Another factor that may have contributed to differences in the reaction of lines to PSD between locations and years may be pathogen diversity. Although not addressed in this study, isolates of $P$. longicolla differ in appearance and pathogenicity. Li et al. (21) evaluated 48 P. longicolla and Phomopsis spp. isolates that were collected from both soybean hosts or nonlegume hosts and from the United States, Canada, and Costa Rica $(11,18)$. Using the cut-stem inoculation method, significant $(P \leq 0.0001)$ differences in stem length and stem lesion length among isolates were found (21). Although the ITS sequence of seven geographically diverse $P$. longicolla isolates were identical (42), some isolates of $P$. longicolla appeared to be more aggressive than other isolates in infecting soybean. Therefore, it is important to choose specific isolates for use in screening lines in the breeding programs that are highly pathogenic. One important question in screening soybean for resistance to PSD is whether specific isolates of $P$. longicolla can overcome specific sources of resistance, and if the ability to overcome resistance is widespread among pathogen populations. The multiple sources of resistance identified in our study could be used to characterize diversity in P. longicolla populations.

Planting PSD-resistant cultivars is the most economical and environmentally friendly means of protecting soybean crops from PSD, especially when using the ESPS in southern states. The new sources of PSD resistance identified in our study can be used in developing soybean breeding lines or cultivars with resistance to PSD, and for genetic mapping of PSD resistance genes. Over 50 breeding and mapping populations with new sources of resistance identified from our studies are being developed (unpublished). Experiments are underway to test those populations to determine the genetics of resistance to PSD, to identify molecular markers for selection of PSD resistance, and to develop high-yielding soybean with PSD resistance in the midsouth.

\section{Acknowledgments}

This research was funded by the United Soybean Board (USB) grants number $9261,0261,1261$, and 2261; and was also partially supported by the United States Department of Agriculture-Agricultural Research Service Projects 6402-21220-012-00D, Crop Genetics Research Unit, Stoneville, MS. We thank A. Clark, X. Gao, B. Holland, G. Sciumbato, A. Steger, S. Sun, B. Yu, L. Zhan, and numerous temporary employees for their assistance with this research.

Table 9. Pearson correlation coefficients between percentage of seed infection with Phomopsis longicolla and germination rate, and seed visual quality in replicated field tests in Arkansas (AR), Mississippi (MS), and Missouri (MO) ${ }^{\mathrm{v}}$

\begin{tabular}{|c|c|c|c|c|c|c|c|}
\hline \multirow[b]{2}{*}{ Year } & \multirow[b]{2}{*}{ Location } & \multirow[b]{2}{*}{$\mathbf{M G}^{\mathbf{y}}$} & \multirow[b]{2}{*}{ Treatment $^{\mathrm{z}}$} & \multicolumn{2}{|c|}{ Germination $^{w}$} & \multicolumn{2}{|c|}{ Visual quality } \\
\hline & & & & $r$ & $P$ & $r$ & $P$ \\
\hline \multirow[t]{9}{*}{2009} & $\mathrm{AR}$ & III & Non & -0.1922 & 0.1768 & -0.0916 & 0.579 \\
\hline & AR & IV & Non & -0.3625 & 0.0099 & 0.2802 & 0.0465 \\
\hline & AR & V & Non & 1.000 & $<0.0001$ & 0.364 & 0.0063 \\
\hline & MO & III & Non & -0.2783 & 0.086 & 0.1551 & 0.3524 \\
\hline & MO & IV & Non & -0.6111 & $<0.0001$ & 0.2392 & 0.148 \\
\hline & MO & $\mathrm{V}$ & Non & -0.2418 & 0.1555 & 0.3881 & 0.0233 \\
\hline & MS & III & Non & -0.2560 & 0.0643 & 0.2273 & 0.1017 \\
\hline & MS & IV & Non & -0.5780 & $<0.0001$ & 0.3819 & 0.0044 \\
\hline & MS & $\mathrm{V}$ & Non & -0.6830 & $<0.0001$ & 0.6178 & $<0.0001$ \\
\hline \multirow[t]{6}{*}{2010} & AR & III & Non & -0.5586 & $<0.0001$ & 0.2927 & 0.0286 \\
\hline & $\mathrm{AR}$ & IV & Non & -0.7404 & $<0.0001$ & 0.3288 & 0.0133 \\
\hline & $\mathrm{AR}$ & $\mathrm{V}$ & Non & -0.5168 & $<0.0001$ & 0.2122 & 0.1164 \\
\hline & $\mathrm{AR}$ & III & Inoc & -0.5502 & $<0.0001$ & 0.2257 & 0.0945 \\
\hline & $\mathrm{AR}$ & IV & Inoc & -0.7485 & $<0.0001$ & 0.3449 & 0.0092 \\
\hline & $\mathrm{AR}$ & $\mathrm{V}$ & Inoc & -0.3638 & 0.0058 & 0.2982 & 0.0256 \\
\hline \multirow[t]{12}{*}{2012} & $\mathrm{AR}$ & III & Non & -0.1208 & 0.3752 & 0.2786 & 0.0376 \\
\hline & AR & IV & Non & 0.1262 & 0.3541 & -0.3344 & 0.0118 \\
\hline & $\mathrm{AR}$ & V & Non & -0.1880 & 0.1734 & 0.04127 & 0.767 \\
\hline & $\mathrm{AR}$ & III & Inoc & -0.0717 & 0.5944 & 0.1043 & 0.4445 \\
\hline & $\mathrm{AR}$ & IV & Inoc & -0.0110 & 0.9358 & -0.0254 & 0.8527 \\
\hline & $\mathrm{AR}$ & $\mathrm{V}$ & Inoc & -0.3546 & 0.0073 & 0.2725 & 0.0422 \\
\hline & MS & III & Non & -0.2378 & 0.0776 & 0.2291 & 0.0894 \\
\hline & MS & IV & Non & -0.2847 & 0.0351 & 0.1475 & 0.2827 \\
\hline & MS & V & Non & -0.1401 & 0.3032 & 0.3797 & 0.0039 \\
\hline & MS & III & Inoc & -0.2303 & 0.0938 & 0.3026 & 0.0262 \\
\hline & MS & IV & Inoc & -0.1722 & 0.2044 & 0.1497 & 0.2707 \\
\hline & MS & $\mathrm{V}$ & Inoc & -0.5513 & $<0.0001$ & 0.4231 & 0.0012 \\
\hline
\end{tabular}

\footnotetext{
${ }^{v}$ Tests at MO and MS in 2010 and at all locations in 2011 were not included because disease pressure was below 5\% and that was not enough disease to adequately compare entries; $r=$ Pearson correlation coefficients and $P=$ probability.

w Percentage of seed germination.

x Seed were assessed using a scale of 1 to 5 , where $1=$ excellent (no bad seed), $2=\operatorname{good}($ less than $10 \%$ bad seed), $3=$ fair $(11$ to $30 \%$ bad seed), $4=$ poor $(31$ to $50 \%$ bad seed), and $5=$ very poor (more than $50 \%$ bad seed). Factors considered in estimating seed quality were development of seed wrinkling, molding, mottling, and discoloration.

y Maturity group.

${ }^{\mathrm{z}}$ Inoculation treatments. Non $=$ noninoculated control sprayed with distilled water and Inoc $=$ inoculated with spore suspension of $P$. longicolla $\left(2 \times 10^{5}\right)$ at the R5 stage.
} 


\section{Literature Cited}

1. Association of Official Seed Analysts. 2001. Rules for Testing Seeds. Assoc. Official Seed Analysts, Las Cruces, NM.

2. Baird, R. E., Abney, T. S., and Mullinix, B. G. 2001. Fungi associated with pods and seeds during the R6 and R8 stages of four soybean cultivars in southwestern Indiana. Phytoptotection 82:1-11.

3. Balducchi, A. J., and McGee, D. C. 1987. Environmental factors influencing infection of soybean seeds by Phomopsis and Diaporthe species during seed maturation. Plant Dis. 71:209-212.

4. Brown, E. A., Minor, H. C., and Calvert, O. H. 1987. A soybean genotype resistant to Phomopsis seed decay. Crop Sci. 27:895-898.

5. Cross, C., Wrather, A., Fothergill, K., Tindall, K., Shannon, G., Li, S., Shumway, C., and Rupe, J. 2012. Effect of lactofen, azoxystrobin, and genotypes on charcoal rot, Phomopsis seed decay and pod and stem blight in soybean. Plant Dis. 96:1154-1158.

6. Fehr, W. R., and Caviness, C. E. 1997. Stages of soybean development. Iowa Agric. Exp. Stn. Spec. Rep. 80. Iowa State University, Ames.

7. Gleason, M. L., and Ferriss, R. S. 1985. Influence of soil water potential on performance of soybean seeds infected by Phomopsis sp. Phytopathology 75:1236-1241.

8. Hartman, G. L., Sinclair, J. B., and Rupe, J. C. 1999. Compendium of Soybean Diseases, 4th ed. American Phytopathological Society, St. Paul, MN.

9. Heatherly, L. G. 1999. Early soybean production system (ESPS). Pages 103-118 in: Soybean Production in the Midsouth. L. G. Heatherly and H. F. Hodges, eds. CRC Press, Boca Raton, FL.

10. Hepperly, P. R., and Sinclair, J. B. 1978. Quality losses in Phomopsis-infected soybean seeds. Phytopathology 68:1684-1687.

11. Hobbs, T. W., Schmitthenner, A. F., and Kuter, G. A. 1985. A new Phomopsis species from soybean. Mycologia 77:535-544.

12. Jackson, E. W., Fenn, P., and Chen, P. 2005. Inheritance of resistance to Phomopsis seed decay in soybean PI 80837 and MO/PSD-0259 (PI 562694). Crop Sci. 45:2400-2404.

13. Jackson, E. W., Feng, C., Fenn, P., and Chen, P. 2009. Genetic mapping of resistance to Phomopsis seed decay in the soybean breeding line MO/PSD-0259 (PI562694) and plant introduction 80837. J. Hered. 100: $777-783$.

14. Jardine, D. J. 1991. The Iowa soybean pod test for predicting Phomopsis seed decay in Kansas. Plant Dis. 75:523-525.

15. Kmetz, K. T., Ellett, C. W., and Schmitthenner, A. F. 1979. Soybean seed decay: Sources of inoculum and nature of infection. Phytopathology 69: 798-801.

16. Koenning, S. R. 2010. Southern United States soybean disease loss estimate for 2009. Page 1 in: Proc. Southern Soybean Dis. Workers 37th Annu. Meet.

17. Li, S. 2011. Phomopsis seed decay of soybean. Pages 277-292 in: Soybean-Molecular Aspects of Breeding. A. Sudaric, ed. Intech Publisher, Vienna.

18. Li, S., Bradley, C. A., Hartman, G. L., and Pedersen, W. L. 2001. First report of Phomopsis longicolla from velvetleaf causing stem lesions on inoculated soybean and velvetleaf plants. Plant Dis. 85:1031.

19. Li, S., and Chen, P. 2013. Resistance to Phomopsis seed decay in soybean. ISRN Agron. 2013:1-8.

20. Li, S., Chen, P., Rupe, J., and Wrather, A. 2010. Reaction of maturity group V soybean plant introductions to Phomopsis seed decay in Arkansas, Mississippi, and Missouri, 2009. Plant Dis. Manag. Rep. 4:ST034. Online publication.

21. Li, S., Hartman, G. L., and Boykin, D. 2010. Aggressiveness of Phomopsis longicolla and other Phomopsis spp. on soybean. Plant Dis. 94:1035-1040.

22. Li, S., Rupe, J., Chen, P., and Wrather, A. 2010. Reaction of maturity group IV soybean plant introductions to Phomopsis seed decay in Arkansas, Mississippi, and Missouri, 2009. Plant Dis. Manag. Rep. 4:ST035. Online publication.
23. Li, S., Smith, J., and Nelson, R. 2011. Resistance to Phomopsis seed decay identified in maturity group V soybean plant introductions. Crop Sci. 51: 2681-2688.

24. Li, S., Wrather, A., Rupe, J., and Chen, P. 2010. Reaction of maturity group III soybean plant introductions to Phomopsis seed decay in Arkansas, Mississippi, and Missouri, 2009. Plant Dis. Manag. Rep. 4:ST036. Online publication.

25. Littell, R., Milliken, G., Stroup, W., Wolfinger, R., and Schabenberger, O. 2006. SAS for Mixed Models. SAS Press. Online publication. http://www. sas.com/apps/pubscat/bookdetails.jsp?pc $=59882$

26. Mayhew, W. L., and Caviness, C. E. 1994. Seed quality and yield of earlyplanted, short-season soybean genotype. Agron. J. 86:16-19.

27. Mengistu, A., Castlebury, L. A., Smith, J. R., Ray, J., and Bellaloui, N. 2009. Seasonal progress of Phomopsis longicolla infection on soybean plant parts and its relationship to seed quality. Plant Dis. 93:1009-1018.

28. Mulik, M. M., and Sinclair, J. B. 1999. Phomopsis Seed Decay. Pages 31-32 in: Compendium of Soybean Diseases. G. L. Hartman, J. B. Sinclair, and J. C. Rupe, eds. American Phytopathological Society, St. Paul, MN.

29. Pathan, M. S., Clark, K. M., Wrather, J. A., Sciumbato, G. L., Shannon, J. G., Nguyen, H. T., and Sleper, D. A. 2009. Registration of soybean germplasm SS93-6012 and SS93-6181 resistant to Phomopsis seed decay. J. Plant Regist. 3:91-93.

30. Roy, K. W., Keith, B. C., and Andrews, C. H. 1994. Resistance of hard seeded soybean lines to seed infection by Phomopsis, other fungi and soybean mosaic virus. Can. J. Plant Pathol. 16:122-128.

31. Rupe, J. C. 1990. Effects of temperature on the rate of infection of soybean seedlings by Phomopsis longicolla. Can. J. Plant Pathol. 12:43-47.

32. Rupe, J. C., and Ferriss, R. S. 1986. Effects of pod moisture on soybean seed infection by Phomopsis sp. Phytopathology 76:273-277.

33. Sinclair, J. B. 1993. Phomopsis seed decay of soybeans-A prototype for studying seed disease. Plant Dis. 77:329-334.

34. Sinclair, J. B. 1999. Diaporthe-Phomopsis. Page 31 in: Compendium of Soybean Diseases. G. L. Hartman, J. B. Sinclair, and J. C. Rupe, eds. American Phytopathological Society, St. Paul, MN

35. Spilker, D. A., Schmitthenner, A. F., and Ellett, C. W. 1981. Effects of humidity, temperature, fertility, and cultivar on the reduction of soybean seed quality by Phomopsis sp. Phytopathology 71:1027-1029.

36. TeKrony, D. M., Egli, D. B., Stuckey, R. E., and Balles, J. 1983. Relationship between weather and soybean seed infection by Phomopsis sp. Phytopathology 73:914-918.

37. TeKrony, D. M., Egli, D. B., Stuckey, R. E., and Loeffler, T. M. 1985. Effect of benomyl applications on soybean seedborne fungi, seed germination, and yield. Plant Dis. 69:763-765.

38. Wrather, J. A., and Koenning, S. R. 2009. Effects of diseases on soybean yields in the United States 1996 to 2007. Online publication. Plant Health Prog. 10.1094/PHP-2009-0401-01-RS.

39. Wrather, J. A., Shannon, J. G., Stevens, W. E., Sleper, D. A., and Arelli, A. P. 2004. Soybean cultivar and foliar fungicide effects on Phomopsis sp. seed infection. Plant Dis. 88:721-723.

40. Wrather, J. A., Sleper, D. A., Stevens, W. E., Shannon, J. G., and Wilson, R. F. 2003. Planting date and cultivar effects on soybean yield, seed quality, and Phomopsis sp. seed infection. Plant Dis. 87:529-532.

41. Xue, A. G., Morrison, M. J., Cober, E., Anderson, T. R., Rioux, S., Ablett, G. R., Rajcan, I., Hall, R., and Zhang, J. X. 2007. Frequency of isolation of species of Diaporthe and Phomopsis from soybean plants in Ontario and benefits of seed treatments. Can. J. Plant Pathol. 29:354-364.

42. Zhang, A. W., Hartman, G. L., Riccioni, L., Pedersen, W. L., and Hartman, G. L. 1998. Molecular identification and phylogenetic grouping of Diaporthe phaseolorum and Phomopsis longicolla isolates from soybean. Phytopathology 88:1306-1314.

43. Zimmerman, M. S., and Minor, H. C. 1993. Inheritance of Phomopsis seed decay resistance in soybean PI 417479. 1993. Crop Sci. 33:96-100. 